\title{
A Lobster Quadrille
}

\section{GenericPoem01: Forms of Radiation}

The wine says a thousand things, moving from sense to information: spiritual. $^{1}$ The city atmosphere is suffused with a variety of sounds, colours, information and odours. "I have," say you, "a certain information of a Deity imprinted in my mind." Information is becoming our primary and universal addiction. ${ }^{4}$ What I want is information: not useful information, of course, but useless information. ${ }^{5}$ Beyond the end, beyond all finality, we enter a paradoxical state - the state of too much reality, too much positivity, too much information. ${ }^{6}$ You gave me plenty of background information. ${ }^{7}$ The entropy increase is always larger than the information obtained. ${ }^{8}$ Newspapers, news, proceed by redundancy, in that they tell us what We "must" think, retain, expect, etc. Language is neither informational nor communicational. ${ }^{9}$ A century of more and more rapid movement of information by print had developed new sensibilities. ${ }^{10}$ They can manipulate several forms of information at the same time, yet they neither understand it, norintegrate it, nor synthesise it as do we, their ancestors. ${ }^{11}$ They seemed to me to embody the same information, just coded in two complementary ways. ${ }^{12}$ Information resides in informed mass, not in a materiality that would be the opposite of immaterial forms. ${ }^{13}$ Information can be changed into negentropy, and vice versa. ${ }^{14}$ The connection between entropy and information is absolutely essential for consistency. ${ }^{15}$ This means that the knowledge is stored not explicitly, but implicitly, in a spread about 
manner, rather than as a local "packet of information." Whether this information is valuable or worthless does not concern us. ${ }^{17}$ The essential point is that all information is paid for in negentropy..$^{18}$ From this negative entropy the demon obtains information. ${ }^{19}$ Knowledge is not gratuitous, information has a price. ${ }^{20}$ An infinite amount of information is unattainable. ${ }^{21}$ We may have fluctuations in the information obtained in individual operations. ${ }^{22}$ The mathematical notion of information does not signify the quantity it captures, it indexes it. ${ }^{23}$ Only if system elements have the chance, here or there, to be open or closed, does the system produce information. ${ }^{24}$ Information is more a matter of process than of storage. ${ }^{25}$ We miss the very character of information when we try to relate it to the passive representation of sense. ${ }^{26}$ But we are in no position to investigate the process of thought, and we cannot, for the moment, introduce into our theory any element involving the human value of the information. ${ }^{27}$ Information is information, not matter or energy. ${ }^{28} I$ admit that, in the present state of my information, I do not understand it. ${ }^{29}$ The information must be carried by some physical process, say some form of radiation. ${ }^{30}$

$\begin{array}{ll}1,4 & \text { Michel Serres, The Five Senses, } \\ 2 & \text { Toyo Ito, Tarzans in the Media Forest, } \\ 3 & \text { Cicero, Tusculan Disputations, } \\ 5 & \text { Umberto Eco, On Literature, } \\ 6 & \text { Jean Baudrillard, The Vital Illusion, } \\ 7 & \text { Sigmund Freud, The Psychopathology of Everyday Life, } \\ 8,14,15,17,18,19, & \\ 21,22,27 & \text { Leon Brillouin, Science and Information Theory, } \\ 9 & \text { Gilles Deleuze and Felix Guattari, A Thousand Plateaus: Capitalism and Schizophrenia, } \\ 10 & \text { Marshall McLuhan, The Gutenberg Galaxy, } \\ 11 & \text { Michel Serres, Thumbelina: The Culture and Technology of Millennials, } \\ 12,16 & \text { Douglas R. Hofstadter, Gödel, Escher, Bach: An Eternal Golden Braid, } \\ 13,20,23,26 & \text { Vera Bühlmann, Mathematics and Information in the Philosophy of Michel Serres, } \\ 24 & \text { Friedrich Kittler, The Truth of the Technological World: Essays on the Genealogy } \\ & \text { of Presence, } \\ 25,28,30 & \text { Norbert Wiener, Cybernetics: Or the Control and Communication in the Animal and } \\ & \text { the Machine, 29 Jacques Derrida, Signature }\end{array}$




\section{GenericPoem02: Composing the Great Bear}

One room was filled with unknown instruments, anotherhad shrunk somuch that he could not enter it; another one had not itself changed, but its windows and doors opened onto great sand dunes. ${ }^{1}$ When I asked him where these machines were, he told me that they had already been made in ancient times, and some even in our own time: "Except the flying instrument, which I have never seen or known anyone who has seen, but I know of a learned man who has conceived it." "He crafted an instrument from cacophony. ${ }^{3}$ The ancients coined a poetic name for such instrumentality: a Cornucopia. ${ }^{4}$ We know that this instrument has been perfected by the long continued efforts of the highest human intellects; and we naturally infer that the eye has been formed by a somewhat analogous process. ${ }^{5}$ We Stoics, therefore, compare the tongue to the bow of an instrument, the teeth to the strings, and the nostrils to the sounding board. ${ }^{6}$ We perceive it when one bubble dissolves another, when medicines attract humors from a similarity of substance, when one string moves another in unison with it on different instruments, and the like. ${ }^{7}$ Keeping this idea definitely in mind, if we imagine a line drawn from the northern side of the circumference $(N)$ to the side which lies above the southern half of the axis $(S)$, and from here another line obliquely up to the pivot at the summit, beyond the stars composing the Great Bear (the pole star P), we shall doubtless see that we have in the heaven a triangular figure like that of the musical instrument which the Greeks call the "sambuca." We shall not therefore pretend to say anything of Modulation, or the particular Rules of any instrument; but only speak of those Points which are immediately to our Subject, which are these. ${ }^{9}$ The assumption was that errors could be made "as small as might be desired, by careful instrumentation, and played no essential role." Mechanical laws are supposed to be reversible in time, but this is true only if errors and experimental uncertainties are completely ignored. ${ }^{11}$ The aesthetic beauty exemplarily achieved here, at the cost of a functional lack, is the beauty of unforeseeable metamorphoses, the conjunction of life's randomness with random vegetation, climate and makeshift instruments. ${ }^{12}$

$\begin{array}{ll}1,3 & \text { Jorge Luis Borges, Collected Fictions, } \\ 2 & \text { Umberto Eco, The Name Of The Rose, } \\ 4 & \text { Vera Bühlmann, Mathematics and Information in the Philosophy of Michel Serres, } \\ 5 & \text { Charles Darwin, On the Origin of Species: A Facsimile of the First Edition, } \\ 6 & \text { Marcus Tullius Cicero, The Tusculan Disputations, } \\ 7 & \text { Francis Bacon, Novum Organum, } \\ 8 & \text { Vitruvius Pollio, The Ten Books on Architecture, } \\ 9 & \text { Leon Battista Alberti, The Ten Books of Architecture, } \\ 10,11 & \text { Leon Brillouin, Science and Information Theory, } \\ 12 & \text { Jacques Ranciere, Aisthesis: Scenes from the Aesthetic Regime of Art. }\end{array}$




\section{GenericPoem03: A New Don Quixote}

The builders of the library were great masters. ${ }^{1}$ One day he rose from his armchair, and went to his library in search of a book. ${ }^{2}$ At the foot of the stairway there was a cell, and then a library, and then a sort of cabinet, or private study, filled with instruments of magic. ${ }^{3}$ The next five floors are devoted to eating, resting and socializing: they contain dining rooms - with a variety of privacies - kitchens, lounges, even a library. ${ }^{4} \mathrm{He}$ had a well selected little library. ${ }^{5}$ There is, in every well-made library, a Hell where live the books that must not be read. ${ }^{6}$ In Pierre Menard's library there is no trace of such a work. ${ }^{7}$ Borges, less of an idealist, decided that his library was like the universe-and one understands then why he never felt the need to leave it. ${ }^{8}$ Even in this case, as Borges warned us, the library would contain the autobiographies of angels and a detailed history of the future. ${ }^{9}$ When it was announced that the library contained all books, the first reaction was unbounded joy. ${ }^{10}$ The true hero of the library of Babel is not the library itself but its Reader, a new Don Quixote, on the move, adventurous, restlessly inventive, alchemically combinatory, capable of overcoming the windmills he makes rotate ad infinitum. ${ }^{11}$ Those examples allowed a librarian of genius to discover the fundamental law of the library. ${ }^{12}$ The library is a sphere whose exact centre is any hexagon and whose circumference is unattainable..$^{13} I \mathrm{de}$ clare that the library is endless. ${ }^{14}$ In all the library, there are no two identical books. ${ }^{15}$ The library is unlimited but periodic. ${ }^{16}$ On a shelf in the library are very old books that tell of another past than the one the dreamer has known. ${ }^{17}$ You see, our library is not like others. " ${ }^{18}$ "So the plan of the library reproduces the map of the world?"19 If a library of the year 3000 came into our hands today, we could not understand its contents. ${ }^{20}$ No one ever leaves the world, but anyone can easily exit the library; we can enter objects infinitely, a book is quickly finished. ${ }^{21}$ Signore professore dottore Eco, what a library you have!"2 "I shall be glad to have the library to myself as soon as may be." 23

$1,18,19$
2,5
$3,7,10,12-16$
4
6
$8,9,11$
17
20
21
22
23

Umberto Eco, The Name Of The Rose,

Victor Hugo, Les Misérables,

Jorge Luis Borges, Collected Fictions,

Rem Koolhaas, Delirious New York: A Retroactive Manifesto for Manhattan,

Maurice Blanchot, The Book to Come,

Umberto Eco, On Literature,

Gaston Bachelard, The Poetics of Space,

F. A. Hayek, The Constitution of Liberty,

Michel Serres, The Five Senses: A Philosophy of Mingled Bodies,

Nassim Nicholas Taleb, The Black Swan,

Jane Austen, Pride and Prejudice. 


\section{GenericPoem04: A Matter of Harmonies}

Nothing has ever been invented by one man in architecture. ${ }^{1}$ Architecture is stifled by custom. ${ }^{2}$ Architecture is a plastic thing. ${ }^{3}$ Architecture is a thing of art, a phenomenon of the emotions [...]. ${ }^{4}$ Architecture is a matter of "harmonies," it is "a pure creation of the spirit." Architecture is a very noble art. ${ }^{6}$ Architecture is governed by standards. ${ }^{7}$ Architecture is stifled by custom. ${ }^{8}$ The "styles" are a lie. ${ }^{9}$ Architecture is very broad. ${ }^{10}$ Architecture is nothing but ordered arrangement, noble prisms, seen in light. ${ }^{11}$ Architecture is based on axes. ${ }^{12}$ Architecture is a plastic, not a romantic, affair. ${ }^{13}$ Architecture is very well able to express itself in a precise fashion. ${ }^{14}$ Architecture is a plastic thing. ${ }^{15}$ Architecture is stifled by custom. ${ }^{16}$ But wait a little, architecture is not only a question of arrangement. ${ }^{17}$ Writing on architecture is not like history or poetry. ${ }^{18}$ For this book does not show of what architecture is composed, but treats of the origin of the building art, how it was fostered, and how it made progress, step by step, until it reached its present perfection. ${ }^{19}$ I would like to emphasise above all that architecture is a game lacking clear rules. ${ }^{20}$ Architecture is at one and the same time a science and an art. ${ }^{21}$ But all the possible alternatives are not in fact realized: there are a good many partial groups, regional compatibilities, and coherent architectures that might have emerged, yet did not do so. ${ }^{22}$ And architecture, too, has this mysterious dimension of the frontier between two worlds of space. ${ }^{23}$ Architecture positions its ensembles - houses, towns or cities, monuments or factories - to function like faces in the landscape they transform. ${ }^{24}$ The house stares through its windows at the vineyards and tufts of thyme, ornamental oranges take shape on its walls, a tissue of lies, oranges and lemons. The philosopher forgets that the house, built around him, transforms a plantation of olive trees into a Max Ernst painting. The architect has forgotten this too. And is happy if the next harvest, outside, is transformed into a Virgin with Grapes, inside. The house transforms the given, which can assault us, softening it into icons: it is a box for generating images, a cavern or eye or camera obscura, a barn which sunlight only illuminates with a slim shaft piercing through the dust-an ear. Architecture produces painting, as though the fresco or canvas hanging on the wall revealed the ultimate cause of the whole structure. The aim of architecture is painting or tapestry. What we took to be mere ornament is its objective, orattheveryleastits end product. Walls areforpaintings, windows for pictures. And padded doors for intimate conversations. ${ }^{25}$ I now held in my hands a vast and systematic fragment of the entire history of an unknown 
planet, with its architectures and its playing cards, the horror of its mythologies and the murmur of its tongues, its emperors and its seas, its minerals and its birds and fishes, its algebra and its fire, its theological and metaphysical controversies - all joined, articulated, coherent, and with no visible doctrinal purpose or hint of parody. ${ }^{26}$ Beyond this stage of perfection in architecture, natural selection could not lead; for the comb of the hive bee, as far as we can see, is absolutely perfect in economising wax. ${ }^{27}$ For architecture, among all the arts, is the one that most boldly tries to reproduce in its rhythm the order of the universe, which the ancients called "kosmos," that is to say ornate, since it is like a great animal on whom there shine the perfection and the proportion of all its members. ${ }^{28}$

Ayn Rand, The Fountainhead,

Le Corbusier, Towards a New Architecture,

Richard Rogers, A Place for All People: Life, Architecture and the Fair Society,

Vitruvius Pollio, The Ten Books on Architecture,

Toyo Ito, Tarzans in the Media Forest,

Jean-Nicholas-Louis Durand, Précis of the Lectures on Architecture,

Michel Foucault, The Archaeology of Knowledge,

Marshall McLuhan, The Gutenberg Galaxy,

Gilles Deleuze, $A$ Thousand Plateaus: Capitalism and Schizophrenia,

Michel Serres, The Five Senses: A Philosophy of Mingled Bodies,

Jorge Luis Borges, Collected Fictions,

Charles Darwin, On the Origin of Species: A Facsimile of the First Edition,

Umberto Eco, The Name Of The Rose. 